\title{
The Economic Crisis and Labour Migration Policy in European Countries
}

\author{
Christiane Kuptsch
}

\begin{abstract}
This paper reviews changes in migration policies as a response to the 2008 financial and economic crisis and examines issues of migration governance. Countries in Europe opted to make new immigration more difficult, protected their labour markets for native born workers, encouraged the return of migrant workers and intensified efforts to curb irregular migration. Clear patterns or reasons for variation in policy responses are not discernible, but it is safe to say that only countries with a significant recent influx of migrants have taken high profile measures at all. The crisis has led to a shift in perspective of the State and its role in economics which is now seen as useful instead of undesired. Previously prevailing neo-liberal thought relegated the State to the "high politics" of sovereignty and security issues. The crisis has highlighted labour market issues, and migrants are now increasingly portrayed as economic agents instead of security threats. This offers room for the State to assert its protective role vis-à-vis migrant workers - a welcome development. The analysis has an International Relations/Political Economy perspective and is largely based on (official) news releases and secondary sources.
\end{abstract}

Keywords: European countries · Financial and economic crisis · Labour migration · Crisis response $\cdot$ Restrictive policies $\cdot$ Migrants as workers $\cdot$ Role of the State

\section{Introduction}

The global economic crisis that started in 2008 has led to a serious slowdown in world economic growth. Enterprises no longer hired new staff; some have resorted to short-time work arrangements (i.e. involuntary part-time employment or unpaid leave); there have been sizeable numbers of lay-offs, oftentimes starting with separations from temporary workers. Although by late 2010 globally speaking economic growth had resumed, in advanced economies, employment is expected to return to pre-crisis levels only by 2015 (ILO 2010). Migrants tend to be among the workers 
most hit by economic downturns for several reasons. From an economic perspective, migrant labour tends to be used as a cyclical buffer much like other macroeconomic policies aimed at maximising growth and minimising unemployment: migrants are often the last to be hired and the first to be fired; their employment relationships are frequently non-standard. From a social and political perspective, in times of economic insecurity migrants easily become scapegoats; xenophobic sentiments and discrimination against migrant workers rise.

This paper provides insights into the impact of the current financial crisis on labour migration flows and on migration policy making. It focuses on affluent migrant receiving countries in Europe, looking at changes in the content of migration policies. What policy changes have occurred since the onset of the crisis? To what extent do the responses of various destination countries converge? What explains variations or similarities? These are some of the questions that will be addressed in the following sections. Final sections 6 and 7 reflect on issues of migration governance and take a more normative perspective. It is suggested that the crisis might have some positive side effects in the area of migration policy making, especially since the crisis has contributed to altering visions of the State and its role in economic policy.

\section{Job shedding in sectors with large migrant employment}

In Europe as elsewhere, migrant workers are particularly concentrated in construction, manufacturing, agriculture, hotel and catering, and health and care work, including domestic services. Some of these sectors are also especially hard hit by the current crisis. Certain economic sectors are more sensitive to business cycles than others. The employment elasticity is particularly high in construction, wholesale and hotels and restaurants - most job shedding has taken place here - but less so in health, social work and education. As the OECD notes, the effect of the economic downturn on migrants depends upon the situation in the country of destination and the impact on migrants is more visible in countries where the crisis began earlier, such as in Ireland, Spain and the United Kingdom (OECD 2009: 7).

Table 1 shows that in these countries, since the onset of the crisis, the unemployment rate for migrant workers has been consistently higher than the rate for the native born labour force. Gaps between native and foreign born workers have tended to increase (see Table 2 for pre-crisis data). In Spain, the unemployment rate of men and women migrant workers combined reached almost $30 \%$ in 2010, and the gap with the native born was more than 10 percentage points following the crisis whereas the gap had been relatively small before.

The above data indicate that migrants in European destination countries are clearly hit by the financial and economic crisis. It appears that women migrant workers may suffer somewhat less from the crisis then male migrants because they tend to work in sectors less affected (such as health and domestic care).

Does this mean that migrants will return to their home countries or seek to find employment elsewhere? And how have host countries dealt with these facts? 
Tab. 1: Unemployment rates for native and foreign born workers (\%), 2009, 2010

\begin{tabular}{lccccc}
\hline \multirow{2}{*}{ Country } & \multicolumn{2}{c}{2009} & \multicolumn{2}{c}{2010} \\
& & Native born & Foreign born & Native born & Foreign born \\
\hline Ireland & $\mathrm{T}$ & 11.2 & 15.4 & 13.0 & 16.3 \\
& $\mathrm{M}$ & 14.4 & 18.2 & 16.5 & 19.2 \\
& $\mathrm{~F}$ & 7.2 & 11.7 & 8.8 & 12.6 \\
Spain & $\mathrm{T}$ & 16.0 & 27.2 & 18.1 & 29.1 \\
& $\mathrm{M}$ & 15.1 & 29.8 & 17.3 & 31.1 \\
& $\mathrm{~F}$ & 17.1 & 24.1 & 19.1 & 26.7 \\
United Kingdom & $\mathrm{T}$ & 7.5 & 8.9 & 7.8 & 9.1 \\
& $\mathrm{M}$ & 8.7 & 8.9 & 8.8 & 9.2 \\
& $\mathrm{~F}$ & 6.1 & 8.9 & 6.6 & 9.0 \\
\hline
\end{tabular}

$\mathrm{T}=$ total; $\mathrm{M}=$ male; $\mathrm{F}=$ female

Source: OECD, Key statistics on migration in OECD countries, Labour market outcomes of immigrants 2008-2010, http://www.oecd.org/dataoecd/18/47/48335145.xls

Tab. 2: Comparison of pre-crisis unemployment rates for native and foreign born workers (\%)

\begin{tabular}{lccccc}
\hline Country & & \multicolumn{2}{c}{ Average } & 1995-2000 & \multicolumn{2}{c}{ Average 2001-2006 } \\
& & Native born & Foreign born & Native born & Foreign born \\
\hline Ireland & T & 8.4 & 10.4 & 4.1 & 5.7 \\
& $\mathrm{M}$ & 8.6 & 10.6 & 4.5 & 5.9 \\
\multirow{5}{*}{ Spain } & $\mathrm{F}$ & 8.1 & 10.2 & 3.7 & 5.5 \\
& $\mathrm{~T}$ & 20.1 & 20.6 & 10.7 & 12.9 \\
\multirow{5}{*}{ United Kingdom } & $\mathrm{M}$ & 14.2 & 15.8 & 7.3 & 9.9 \\
& $\mathrm{~F}$ & 26.3 & 25.4 & 14.1 & 15.9 \\
& $\mathrm{M}$ & 6.7 & 10.0 & 4.6 & 7.4 \\
& $\mathrm{~F}$ & 7.8 & 11.3 & 5.1 & 7.7 \\
\hline
\end{tabular}

$\mathrm{T}=$ total; $\mathrm{M}=$ male; $\mathrm{F}=$ female

Source: OECD, International Migration Outlook SOPEMI, 2008 Edition, Part IV Recent Changes in Migration Movements and Policies: 251, 279, 287, 289. 


\section{Options for migrants: return, move on or stay?}

Unemployment of migrant workers does not mean that they will automatically leave their host countries. In fact, a September 2009 report by the Migration Policy Institute finds that roughly one year after the beginning of the crisis, "immigrants overwhelmingly are choosing to stay put in their adopted countries rather than return home despite very high unemployment and lack of jobs" (MPI 2009: 5).

Whether the migrants wish to go back to their home countries or move on to a third country will largely depend on prospects in these countries. ${ }^{1}$ For example, Polish migrants in Ireland and the UK have moved back in large numbers with growing opportunities in Poland and contractions in the host country economies. Sumption and Somerville (2009) estimate that some 1.5 million workers from the eight Eastern European countries that joined the EU in 2004 (the "A8" countries) came to the UK between May 2004 and September 2009, ${ }^{2}$ and that almost half of them had gone back by the end of 2008. Not only did prospects in Poland improve, but past income differentials constituted a clear incentive to migrate and have melted down due to exchange rate adjustments. In 2003, the monthly average wage in Poland was $£ 800$, whereas in England it was more than double. However, the value of the British currency decreased in relation to the Polish zloty, from $f 1$ equal to 7.23 zloty in 2004 to $f 1$ equal to 4.83 zloty in $2008 .^{3}$

Situations where circulation between countries is easy for the migrants represent incentives to return (Cassarino 2008). Such a situation is given in the case of Polish workers in the UK and Ireland as these two countries have fully recognised EU freedom of movement provisions so that workers from the 2004 accession countries can work in Ireland and the UK without restrictions. In the latter country, all that is required is registration under the Workers Registration Scheme (WRS) but there is no labour market test that gives preference to UK workers, and there are no quotas. ${ }^{4}$ Similarly, Eastern European workers with EU passports quit Spain knowing that they can come back without problems from 2011 when freedom of movement regulations become effective in all EU-15 Member States; and so do some Moroccans with permanent resident status in that country.

The migrants' personal characteristics and situations will also determine their options, such as their educational attainment, their reasons for having migrated (e.g. to join a family member), their immigration status and their length of stay in the country of destination. The latter will often determine their eligibility for welfare

1 For a discussion see Awad (2009), OECD (2009).

2

Sumption and Somerville estimate these numbers in taking the total number of approved Worker Registration Scheme (WRS) applications $(1,001,475)$ and multiplying it by 1.49 to account for some $33 \%$ of $A 8$ workers that are estimated not to register with the scheme. This follows a methodology developed by Pollard, Latorre and Sriskandarajah in 2008 (Sumption/Somerville 2009: 13, footnote 7).

3 Home Office and Poland's statistic office in Alexi Mostrous and Christine Seib "Polish plumbers pack their bags as pickings get richer back east", 16 February 2008, The Times.

4 Not all A8 workers register with the WRS; it is estimated that about one third of the migrants do not, see above. 
benefits in the host country. Migrant workers who have long been in a country of destination are also more likely to have established roots and set up networks that help them withstand the effect of job losses in times of crisis. This ability to adjust will be reinforced if the workers enjoy a regular status.

Many temporary foreign worker schemes do not allow change of employer, while more permanent migrant workers can change their employer and they are also entitled to unemployment and other welfare benefits to bridge the job seeking time. Migrants in irregular situations can of course not make claims to social benefits but their employment opportunities might actually be better than those of migrants under certain temporary schemes - their informal employment is less costly to employers who might hire them, faced as they are with tighter credit and lower revenues. The outcome for the migrants may then be that their conditions of work worsen drastically (wages, working hours, etc.).

Generally it is assumed that people with higher educational attainment will find it easier to adjust to job losses. In recent years there has been outright competition for global talent, for highly skilled migrant workers, with destination countries facilitating their admission and employment. There was what can be labelled a "human capital mercantilism" with policy makers arguing that having more highly skilled migrants was a rational move to raise the productivity and the competitiveness of the destination countries' economies (Kuptsch/Pang 2006). Overall it should therefore be safe to say that highly skilled migrants will be less affected by the financial and economic crisis. ${ }^{5}$

\section{$4 \quad$ Host country reactions: Restrictive policies}

In view of rising unemployment numbers among migrant workers and in line with increasingly protectionist attitudes in other areas such as trade, authorities in destination countries around the world rapidly reacted to the crisis by attempting to make new immigration more difficult, protect labour markets for native born workers, clamp down on migrants in irregular situations and encourage the return of migrant workers. Measures were often taken as a result of public pressures, including in Europe.

There is consensus in the economic literature that in the longer run new immigrants have very little or no impact on labour market outcomes for the pre-existing population (e.g. in terms of earnings or unemployment). For example, theoretical studies invalidate the replacement postulate, i.e. the frequent assumption that immigrants occupy the jobs of native workers. An economy tends to create jobs in proportion to the number of its residents and consumers, and immigrants eventually help to create a number of jobs in proportion to the size of their community. Empirical studies find that the overall economic impact of immigration is small, though

5 This does not mean that they stay unaffected. For a detailed analysis see Cerna (2010). 
opinions are mixed regarding whether the impact is small positive, small negative or zero. ${ }^{6}$

Yet, in the political arena these propositions keep being challenged. Research in European countries has also shown that different opinions about admitting migrants are impacted more by cultural than by economic cost-benefit perceptions, i.e. people are more concerned about the effects that migrants may have on changing the neighbourhood than about their impact on wages (Card/Dustmann/Preston 2009).

\subsection{Reduced inflows and intensified efforts to curb irregular migration}

In the United Kingdom, a number of changes were made to the relatively new PointsBased System (PBS), adopted in February 2008 for assessing immigration applications. This system re-categorised over 80 different routes to employment and education in the UK to just five tiers: Tier 1: highly skilled individuals (previously Highly Skilled Migration Programme); Tier 2: skilled workers with a job offer to fill gaps in the UK labour force; Tier 3: low skilled workers to fill temporary labour shortages; Tier 4: students wanting to come to the UK to study, including student nurses; and Tier 5: youth mobility and temporary workers. Under the PBS, migrant workers and students must gain points to qualify for each specific tier before they can apply for permission to enter, or remain in, the UK. Points are awarded, depending on the tier, based on the qualifications, experience, age, earnings, maintenance and language competence of the candidate. ${ }^{7}$

The UK Home Office strengthened the labour market test for high demand occupations such as civil engineers and nurses. This will affect migrants who seek entry under Tier 2 of the UK Points-Based System (PBS), i.e. non EU-nationals with a confirmed job offer in a sector of labour market shortage. Employers must now advertise jobs to resident workers through the national employment service (JobCentre Plus) before being able to recruit a worker from outside of the European Union. The UK also tightened the criteria against which highly skilled migrants, eligible for coming to the country under Tier 1 of the PBS, are judged. The minimum qualifications were raised to a masters degree and the required salary to at least $£ 20,000$ (MP) 2009: 57). Tier 3 of the PBS, covering low skilled workers to fill temporary labour shortages, was in any case suspended.

France responded to the crisis by making it harder for migrants to live and work in the country illegally. In September 2009, French authorities dismantled and bulldozed a camp of undocumented migrants outside Calais, rounding up almost 300 Afghans, Pakistanis and others who had gathered there for years in the hope of making clandestine journeys across the Channel to Britain. Earlier in the year, highprofile worksite raids had taken place in the region (New York Times, 22 September 2009, and 21 April 2009).

6 For a detailed analysis see Sweetman 2010 (on North America) and Domingues Dos Santos 2010 (on Europe)

7 For more information see: http://www.immigrationmatters.co.uk/uk-immigration. 
Italy went further in this direction and passed legislation criminalising unlawful presence, increasing the maximum period of detention of migrants in irregular situations and prohibiting access to public services such as emergency medical care and education to unauthorised migrants. In addition, citizen patrols got permission to assist police in responding to immigration violations (MPI 2009: 57). Italy also lowered its quota for entries. The 2009 ceiling for entries was capped at 150,000, i.e. 20,000 less than in 2007. Entry was essentially limited to domestic work and only taking applications from the backlog with the government arguing that most applicants were already in Italy without documents (OECD 2009: 25).

In Spain, the Contingente (the quota for workers to be recruited anonymously from abroad) was set at 901 for 2009 versus 15,731 in 2008. In October 2008, the Régimen General (list of difficult to cover occupations) contained $32 \%$ fewer occupations than the previous list and the occupations which were taken from the list represented almost all hiring from abroad. Mostly specific qualified occupations (such as neurosurgeon, dentist, and physiotherapist) remained (OECD 2009: 26). Spain therefore is one of the countries where highly skilled migrants might be less affected by the crisis.

\subsection{Return programmes}

In response to increasing numbers of migrants applying for social benefits, Spain also introduced a voluntary return programme for unemployed legally resident migrants (from 20 non-EU countries having social security agreements with Spain). It was estimated that between some 90,000 and 140,000 people would re-migrate under this plan $^{8}$ where unemployed migrant workers who are registered with the Public Employment Service commit to not returning to Spain for three years. ${ }^{9}$ The payment is made in two lump sums, a first one in Spain (40\%) and a second in the origin country $(60 \%) .{ }^{10}$ Less migrants than expected have shown interest. ${ }^{11}$ In addition, the Spanish Public Employment Service has started to work with its Romanian counterpart to recruit Romanians to return home (OECD 2009: 29).

Similarly, the Czech Republic set up a voluntary return programme where applicants must be legal, non-EU residents, holding a valid residence permit. Some analysts say that the economic crisis was one of the reasons to limit foreign workers' presence in the Czech Republic but that irregular migration, especially from Vi-

8 The Economist, "Global Migration and the Downturn" 15/01/2009 cites a number of 87,000; the Migration Policy Institute says "The government estimated that 140,000 unemployed workers would be eligible to participate" (MPI 2009: 67).

9 The migrant worker is supposed to return together with all other family members who do not have an independent residence permit and who have used the family reunion policy to come to Spain and obtain a resident permit.

10 http://www.planderetornovoluntario.es/index_uno.html.

11 Official figures report some $20^{\prime} 000$ returns between the launch of the programme and late 2010. See http://www.simplynetworking.es/news-6985-31-the_number_of_immigrants_in_spain_is_ falling_as_migrant_workers_return_home.html. 
etnam and Mongolia, had already started to undermine foreign worker admissions before the crisis. Therefore, combating the factors leading to irregular migration, such a regulating unscrupulous labour intermediaries, would make sense, in particular since many Vietnamese appeared to have well integrated into Czech society, having learned the language and occupying posts shunned by locals or being selfemployed (Plewa 2009).

\subsection{Sweden as a deviant case}

In December 2008, Sweden introduced a new immigration law that made it easier for non-EU migrants to work in the country. Decisions on the need for foreign workers will now be made by employers, and no longer a central government body. Under the new system, once a job vacancy has been advertised nationally and across the EU for two weeks, companies can choose to recruit from elsewhere and need only inform the Swedish Migration Board whose role it will be to ensure that working conditions and terms of employment for migrants are equal to those of Swedish employees. Previously, unions had to be consulted before workers were hired from abroad and the national employment agency required proof that the skills were not available at home. The new law opens up Sweden's labour market to workers of all skill levels. The rules also allow asylum seekers whose applications have been refused to be granted work permits if they were employed in Sweden for six months at least and make it easier for foreign students to get work. Immigrants receive work permits for up to four years, after which they qualify for permanent residence. Migration minister Tobias Billström justified the policy changes by referring to the crisis and said: "It's especially important during a downturn to ensure that businesses capable of expanding their activities are able to do so without being hindered by unnecessary bureaucracy." (Sullivan, The Irish Times, 12 December 2008)

\section{Categories of policy changes and assessment}

The above account has summarised changes in migration policy, introduced after the onset of the crisis, which have "hit the news".

Before indicating some of the reasons for States not to take major measures and keep policies stable, an attempt is made in table 3 to categorise the host country reactions described above, according to possible policy changes at different levels.

Policy changes can come at three broad levels. They can be made by (i) introducing new rules, (ii) adapting existing rules without touching the overall structure of the system, and (iii) applying rules differently.

Nothing much is known about how countries apply existing rules, therefore the empty spaces in table 3 under point (iii). It could very well be that a different application leads to tighter de facto policies. Where only administrative procedures change, these do not always have to be publicly discussed and be fully transparent to the social partners or the population. Labour market tests are an example. Public authorities exercise a significant degree of discretion in judging the good faith of 
Tab. 3: Categories of policy changes

\begin{tabular}{|c|c|c|}
\hline Level of change & Examples of policy changes & Country examples \\
\hline \multirow[t]{2}{*}{ (i) New rules } & $\begin{array}{l}\text { New legislation is introduced, } \\
\text { policies are reversed }\end{array}$ & $\begin{array}{l}\text { New Swedish immigration } \\
\text { policy } \\
\text { Italy's new legislation on } \\
\text { criminalising migrants in } \\
\text { irregular situations }\end{array}$ \\
\hline & $\begin{array}{l}\text { New programmes are } \\
\text { introduced }\end{array}$ & $\begin{array}{l}\text { Return programmes in the } \\
\text { Czech Republic and Spain }\end{array}$ \\
\hline \multirow[t]{4}{*}{ (ii) Adaptation of rules } & $\begin{array}{l}\text { Points systems raise the } \\
\text { "pass mark" }\end{array}$ & $\begin{array}{l}\text { United Kingdom: Tier } 1 \text { of the } \\
\text { PBS }\end{array}$ \\
\hline & $\begin{array}{l}\text { Criteria for labour market } \\
\text { tests become tighter }\end{array}$ & $\begin{array}{l}\text { United Kingdom: Tier } 2 \text { of the } \\
\text { PBS }\end{array}$ \\
\hline & $\begin{array}{l}\text { Shortage occupation lists are } \\
\text { reduced }\end{array}$ & Spain: Régimen General \\
\hline & $\begin{array}{l}\text { Numerical limits (quotas, } \\
\text { targets, caps) are reduced }\end{array}$ & $\begin{array}{l}\text { Italy: entry quota } \\
\text { Spain: Contingente }\end{array}$ \\
\hline \multirow[t]{3}{*}{$\begin{array}{l}\text { (iii) Application of } \\
\text { rules }\end{array}$} & $\begin{array}{l}\text { Labour market tests are done } \\
\text { with more scrutiny }\end{array}$ & \\
\hline & $\begin{array}{l}\text { Labour inspection becomes } \\
\text { more frequent / targets } \\
\text { sectors and workplaces with } \\
\text { a high concentration of } \\
\text { migrants }\end{array}$ & $\begin{array}{l}\text { French high profile worksite } \\
\text { raids }\end{array}$ \\
\hline & $\begin{array}{l}\text { Rules on service delivery are } \\
\text { not applied, e.g. more } \\
\text { backlogs are allowed with } \\
\text { regard to visa procedures } \\
\text { and work permit delivery }\end{array}$ & \\
\hline
\end{tabular}

Source: own design

employers in properly advertising their job offers. Another example is labour inspection. Labour inspection can be used to make sure that migrant workers benefit from equal treatment with local workers (e.g. concerning their wages and working conditions) but it can also be used to identify migrants in irregular situations for subsequent expulsion.

\subsection{Policy changes vs. stable policies}

There is not enough evidence to state that structural or systemic differences such as a different organisation of the welfare state (Esping-Andersen 1990) explain or have influenced the types of crisis responses taken or that there are any other clearly discernible patterns. 
The countries that most hit the news with their policy changes were also the ones that had lately seen the biggest inflows of migrant workers and where migrants were having a significant effect on employment growth (the UK and Ireland, Southern European countries, the Czech Republic). The Migration Policy Institute reports that nearly seven in ten new workers in the United Kingdom were migrant workers for example (MPI 2009: 6). This corroborates the thesis of migrant workers being used as cyclical buffers.

European countries that had not opened their doors to the $2004 \mathrm{EU}$-accession countries and had followed a "welcome-the-skilled and rotate-the-unskilled" policy (Kuptsch/Martin 2011: 34) kept this in place. In Germany, for example, where a new immigration policy favouring highly skilled inflows had been introduced in 2005, this has not been touched. Major changes in comparison to the "old system" include the following. The previous five titles of legal residence were reduced to two, a temporary residence permit (befristete Aufenthaltserlaubnis) and a settlement permit (unbefristete Niederlassungserlaubnis). While the recruitment stop persists for low and semi-skilled persons, highly qualified migrants have access to a settlement permit from the beginning. The same favourable conditions also exist for people who invest at least EUR 1 million or create at least ten jobs. Foreign students may stay up to one year after their graduation in Germany to find a job; previously, most non EUstudents had to leave within 90 days. ${ }^{12}$ In the recent past, Germany has also relied substantially on migrants for seasonal agricultural work and introduced no changes to this programme. Indeed, rural employment tends to be relatively stable in affluent destination countries and seasonal agricultural labour migration programmes therefore unaffected by the crisis.

There are certain flows of migrants that countries cannot restrict rapidly or cannot restrict at all, as restrictions would imply human rights violations or non-respect of rights that migrants have acquired. Humanitarian flows and family reunification are cases in point.

Policy changes are also not always possible because of multilateral and bilateral commitments. Where countries have undertaken to accept the free movement of labour within regional integration areas such as the European Union for example, they cannot easily step down from their obligations. Similarly, a number of European countries have concluded bilateral agreements that fix (usually annual) quotas for temporary work of migrants in certain sectors of the economy. Where such agreements are based on memoranda of understanding (MoUs) between employment services instead of international treaties they might be more easily dissolved, nonetheless this requires negotiations, and recruitment stops cannot simply be announced unilaterally. Germany for example brings in nursing and care personnel from Croatia and Slovenia based on memoranda of understanding between

12 For more details and the history of the 2005 immigration reform in Germany see Martin/Abella/ Kuptsch (2006: 98-102). 
the German Employment Service and its foreign counterparts. ${ }^{13}$ Austria, France, Germany and Switzerland all have trainee programmes in place, founded on either MoUs or bilateral agreements.

Labour migration policies do not exist in a vacuum and although labour shortages remain the principle reason for today's temporary foreign worker schemes, foreign policy considerations loom large in several programmes. For example, Poland made employment of its workers an issue during negotiations on the recognition of the Polish-German border. Italy and Spain opened legal migration channels to Albania and Morocco in part to encourage cooperation with these governments in the fight against irregular migration. Other objectives in setting up migration programmes include the wish to promote cultural exchange or development in the migrants' countries of origin. Migration restrictions could reinforce the crisis in sending countries resulting in increased irregular migration, an extremely undesired outcome for destination countries. Trade relations and dependencies on supplies of particular commodities and/or energy from migrant sending countries may also cause receiving countries to refrain from adopting restrictive policies.

This shows that there are quite a few reasons for countries not to openly change their policies despite the economic and financial crisis. And what might be the expected life span of those changes that were introduced?

\subsection{Permanent changes? (Short-term and long-term effects of policy changes)}

Shortage lists and numerical limits (so far as the latter are not fixed in bilateral agreements) can easily be adapted and can have a rapid impact on migration flows. Points systems can raise pass marks but also quickly bring them back down again. Where labour market tests become stricter either via tighter rules or because they are done with more scrutiny, this can also be rapidly reversed. And more or less staff and financial resources can be allocated to visa and work permit delivery, yielding expanded or reduced immediate inflows. The adaptation of existing rules and their different application tend to be less permanent in nature and more easily to be reversed than new pieces of legislation.

Therefore, both the new Swedish immigration policy and Italy's new legislation on criminalising migrants will be more difficult to repeal than the cap on migrants' inflows under the Spanish Contingente. However, are these legislative reforms in Italy and Sweden really products of the financial and economic crisis or has the crisis only been used to justify changes that would have occurred anyway given political constellations?

In Italy, the legislative changes are very much in line with pre-crisis policy stands on migrants and immigration taken by the Berlusconi government.

13 For the programme rules see ZAV (2004). 
The Swedish reform with its liberal provisions on labour migration and its deferral to employers of immigration decisions, appears to be more the result of a particular political set up than a direct consequence of the crisis. Cerna (2009) convincingly explains how immigration policy in Sweden is the outcome of coalition building and shifting coalitions over time between native high-skilled labour, native low-skilled labour and capital. In 2006 the government changed with the centreright coalition government presenting a more capital-oriented position, weakening the link between unions and the government (p. 37).

Assisted voluntary return programmes, such as now implemented in Spain and the Czech Republic, tend to linger on as the historical experience of the Netherlands, France and Germany shows. European return programmes emerged for the first time after the 1973 oil crisis had led to a recession. All of them had a long life span and were considered unsuccessful. In 1974 the Netherlands launched their 'Reintegration of Emigrant Manpower and Promotion of Local Opportunities for Development' programme which lasted until the mid 1980s and focussed on entrepreneurial ventures. Around the time when the Dutch programme closed down, the German 'Act to Promote the Preparedness of Foreign Workers to Return' was passed, in 1983. The German scheme was discontinued in the early 1990s only, despite a low take up rate. It offered cash payments to returning migrants similarly to the French Aide au retour programme of 1977 . The latter was aimed at migrants from North and West Africa, especially Algerians, but was mainly used by Portuguese and Spanish migrants in France. In the period 1977 - 1981 some 60,000 migrants returned (out of which only $4 \%$ were Algerians), not exactly meeting the declared target of 1 million returnees (Sward 2009).

All in all, it seems fair to conclude that the crisis has not led to major system changes in European countries. It has mainly led to an adaptation of existing rules, and possibly to a different application of rules, which can both be reversed rapidly.

\section{The crisis as an opportunity: A new perspective on migration governance?}

States have the responsibility for protecting migrant workers from abuses and ensuring that they actually enjoy the equal treatment and equal opportunity rights that exist under international law, as for example set out in ILO Conventions No. 97 and $143 .{ }^{14}$ In practice, it is the role of Ministries of Labour and employment services and

14 ILO Convention No. 97, adopted in 1949, in a context of (anticipated) migration flows in the aftermath of World War II is about migration management while protecting workers crossing borders. It aims to ensure equal treatment for them by encouraging countries to sign bilateral agreements. Convention No. 143 (1975) was enacted after oil-price hikes led to recessions in European countries that had been importing large numbers of guest workers and stopped recruitment as a response to the economic downturn. C143 deals with clandestine migration (to be expected with legal channels being closed) on the one hand (Part I) and with equality of opportunity and treatment and the integration of settled migrants on the other (Part II). 
other institutions supervised by Ministries of Labour to administer protective programmes and make sure that non-discrimination norms are respected.

The crisis may mean an opportunity as it has shifted perspectives and may lead to an expanded role of Labour Ministries in migration policy making. First, perspectives on the State and State action in general seem to have evolved; and second, as concerns migration policy, the crisis has brought more of a focus on labour policies and less on security issues, as will be argued in the following.

Since approximately the 1980s (the Reagan-Thatcher years) neo-liberal thought with its particular vision of the State has dominated economic and social policy making in Europe. Neo-liberalism is very much a theory about economic arrangements, e.g. against State interference with private property and in market exchanges. The focus is on free markets. "Classical" liberalism in contrast is primarily about human freedoms, protecting individuals from unacceptable State incursions on their liberty, and ensuring that all individuals within the polity are able to enjoy these rights. Liberalism is also the theory that highlights the equal treatment of all individuals irrespective of their particular characteristics; the universal applicability of liberal rights; and the need to limit State power over the individual (Hansen 2011).

Glivanos (2008) points out that current neo-liberal thought combines two strands of classical theory, especially to explain the function of private property: The Austrian tradition views market individualism as maintaining individual freedoms (Hayek, Ludwig von Mises, Schumpeter) while neoclassical economists emphasise the importance of markets to achieve efficiency (Chicago School of Economics). HaJoon Chang (2002) views this combination as an "unholy alliance" that results in an unfavourable perception of the State and its role. The State is no longer seen in its benevolent function, as under Keynesianism; it has lost its role as impartial arbiter and social guardian. Instead, the State is perceived as an organisation catering to self-interested bureaucrats and politicians who work for their client groups and not in the general interest.

This vision of the State also goes hand in hand with the thought that there are "high politics" and "low politics", with sovereignty and security issues figuring at the high end, in contrast to economic, labour and social policy. ${ }^{15}$ At most the State should be in charge of "high politics" but preferably not interfere in other issues and leave them to market regulation. Indeed, the State's role in security issues is less contested by neo-liberal thought. Labour Ministries, on the other hand, have been accused of being "spending ministries" open to group interest pressure. For Labour Ministries this has meant an erosion of their role: a shrinking of their responsibilities and cutbacks in budget allocations. Their human, material and symbolic resources have increasingly paled (Minet 2001).

One of the areas, in which the role of the Labour Ministries has been reduced, is migration. At EU level the Directorate-General (DG) Home (i.e. internal affairs) and to some extent the DG External Relations drive much of the migration policy making,

15 These concepts come out of the Realist school of thought in International Relations theory. For a criticism of this dichotomy, see e.g. Ripsman (2004). 
not leaving this to their colleagues in the DG Employment, Social Affairs and Inclusion (which would correspond to the Labour Ministry at the national level). France created a new Ministry for Immigration, Integration and Identity in 2007. Migration had previously been a responsibility of the Labour Ministry. In the United Kingdom migration issues are dealt with by the Home Office (the Ministry of the Interior); it is the UK Border Agency that publishes approved shortage occupation lists.

The current financial and economic crisis is seen by many as the result of too much (neo-liberal) market focus and neglect of (liberal) rights-based approaches. States have been essential in stabilising financial and economic systems, challenging the view that markets are best left alone.

As concerns migration, the crisis has highlighted labour market issues. Migrant workers made the news as economic agents, not as security threats, criminals or potential terrorists as was often the case before the crisis. The media and certain politicians have not always portrayed migrants as positive economic agents ("they take away our jobs and should be sent home - local workers first", see e.g. the analysis by Castles and Vezzoli 2009). Nonetheless this type of headlines has shifted the discussion to economic questions.

The crisis has also sharply reduced prospects for migrants to find a job in European destination countries without a prior job offer, work permit and other papers. The El Dorado image of Europe suffered, leading to less people trying to enter without authorisation, at least in the period before the so-called "Arab Spring" of 2011. Research in the United States indicates a strong correlation between the flows of unauthorised migrants and economic opportunities in the country (in politically stable times). For example US Border Patrol apprehensions data show that fluctuations in migrant apprehension are closely related to labour demand (Passe//D'Vera 2009). Similarly, a post-crisis Frontex ${ }^{16}$ analysis reported a decline in illegal border crossing in the European Union: the number of illegal border crossings in the first quarter of 2009 was $16 \%$ lower than one year earlier. For the first time in years, not a single immigrant boat was intercepted off the Canary Islands in the spring of 2009, according to the Spanish Interior Ministry (MPI 2009: 22-23).

Border controls are normally the number one rapid reaction by States to stem the flow of migrants. If these are less necessary because the border is no longer "threatened", this could additionally shift attention away from security issues towards labour and employment questions.

Neo-liberal (market-based) approaches to labour migration tend to look at overall (global) gains from migration and less at distributional effects. They see migrants as rational actors who may be willing to accept unfavourable labour conditions in host countries because these may still be better then what they would find at home or because they are simply faced with extremely limited options. Liberal (rights-based) approaches, on the other hand, include the notion that the State has a protective

16 Frontex is a EU agency based in Warsaw, created as a specialised and independent body tasked to coordinate the operational cooperation between Member States in the field of border security. 
function, including also protecting people from themselves and some of their own decisions, e.g. to submit themselves to abuse.

With a revival of the State in the economic arena, a renewed view of migrants as workers and more liberal (rights-based) approaches to policy making in general, there should be room for Labour Ministries to assert their protective role vis-à-vis migrant workers.

\section{Conclusions and outlook}

The preceding sections have shown that migration policy reactions to the financial and economic crisis were essentially of four types. Countries in Europe opted to make new immigration more difficult, protect labour markets for native born workers, clamp down on migrants in irregular situations and encourage the return of migrant workers. Clear patterns or reasons for variation in policy responses are not discernible, but it is safe to say that only countries with a significant recent influx of migrants have taken high profile measures at all.

The trend was for reactions to be in the form of an adaptation and tighter application of existing rules. This is understandable as legislative reforms, especially in an area as sensitive as migration policy, tend to be lengthy processes. They require preparations and negotiations. Where they occurred, as in Sweden and Italy, they can be traced back to pre-crisis developments such as shifting coalitions and particular political constellations.

Manifold constraints in areas such as trade, development and foreign policy also prevented countries from strong reactions against migrants, as did obligations undertaken in bi- and multilateral agreements and the existence of migrants' acquired rights. Especially countries with a "welcome the skilled, rotate the unskilled" policy in place prior to the crisis have seen no need for implementing changes that would have led to a wide publicity.

Migrant workers have contributed to creating wealth and development in their host countries but the crisis has produced a climate of protectionism, an environment where this proposition is being challenged. One needs to devise strategies that reinforce the recognition of the positive role of migrant workers and protect them.

It will also be important to look at the longer term, beyond the crisis. For example, voluntary return programmes in response to the crisis will have to be assessed in terms of the messages they convey and whether it makes sense to have migrants return to their home countries who have made efforts to integrate and whose labour force may be needed soon again.

To reinforce the respect for rights at all levels will be crucial: national labour legislation, international labour standards, and general human rights law. This will include to closely monitor the application of labour laws to migrant workers (conditions of work, minimum employment standards, etc.); check whether labour laws and labour migration policies correspond to international labour standards; and in efforts to curb irregular migration, strictly observe international human rights law. 
On the positive side, the crisis has led to a shift in perspective about the State and its role in economics which is now seen as useful instead of undesired. Previously prevailing neo-liberal thought relegated the State to the "high politics" of sovereignty and security issues. The crisis has highlighted labour market issues, and migrants are now increasingly portrayed as economic agents instead of security threats. This offers room for the State to assert its protective role vis-à-vis migrant workers - a welcome development.

\section{References}

Awad, Ibrahim 2009: The Global Economic Crisis and Migrant Workers: Impact and Response. Second Edition. Geneva: ILO. [http://www.ilo.org/public/english/protection/ migrant/download/global_crisis2.pdf, 23 July 2012].

Card, David; Dustmann, Christian; Preston, lan 2009: Immigration, Wages, and Compositional Amenities. CReAM Discussion Paper Series 0929, Centre for Research and Analysis of Migration (CReAM), Department of Economics, University College London. URL: http://www.cream-migration.org/publ_uploads/CDP_29_09.pdf, 23 July 2012.

Cassarino, Jean-Pierre 2008: Patterns of Circular Migration in the Euro-Mediterranean Area: Implications for Policy Making. CARIM Analytical and Synthetic Notes 2008/29. Circular Migration Series. European University Institute, Robert Schuman Centre for Advanced Studies. [http://cadmus.eui.eu/bitstream/handle/1814/8350/CARIM AS\%26N_2008_29.pdf?sequence=1, 23 July 2012].

Castles, Stephen; Vezzoli, Simona 2009: The global economic crisis and migration: temporary interruption or structural change? In: Paradigms, 2009, 02. [http://www.gencat. cat/diue/doc/doc_86200114_3.pdf, 23 July 2012].

Cerna, Lucie 2009: Changes in the Swedish Labour Immigration Policy: A Slight Revolution? Working Paper 2009:10, The Stockholm University Linnaeus Center for Integration Studies (SULCIS). URL: http://ideas.repec.org/p/hhs/sulcis/2009_010.html, 23 July 2012.

Cerna, Lucie 2010: Policies and practices of highly skilled migration in times of the economic crisis. International Migration Papers No. 99, Geneva: ILO. [http://www.ilo.org/ public/english/protection/migrant/download/imp/imp99.pdf, 23 July 2012].

Chang, Ha-Joon 2002: Breaking the mould: an institutionalist political economy alternative to the neoliberal theory of the market and the state. Cambridge Journal of Economics 26, 2002: 540 [doi: 10.1093/cje/26.5.539].

Domingues Dos Santos, Manon 2010: Immigration and unemployment: A European perspective. In: Kuptsch, Christiane (ed.): The Internationalization of Labour Markets. Geneva: ILO/IILS. [http://www.ilo.org/public/english/bureau/inst/download/interlabour. pdf, 23 July 2012].

Esping-Andersen, Gosta 1990: The Three Worlds of Welfare Capitalism. Princeton University Press.

Glivanos, loannis 2008: Neoliberal Law: unintended consequences of market-friendly law reforms. In: Third World Quarterly 29,6: 1087-1099 [doi: 10.1080/0143659080 2201055].

Hansen, Randall 2011: The two faces of liberalism. In: Journal of Ethic and Migration Studies 37,6: 881-897 [doi: 10.1080/1369183X.2011.576192]. See also: http://www.tvo. org/theagenda/resources/pdf/Liberalism2006.pdf. 
ILO (International Labour Office) 2010: World of Work Report 2010: From one crisis to the next? Geneva: ILO. [http://www.ilo.org/public/english/bureau/inst/download/ wow2010.pdf, 23 July 2012.]

Kuptsch, Christiane; Martin, Philip 2011: “Low-skilled labour migration." In: Betts, Alexander (ed.): Global Migration Governance. Oxford: Oxford University Press: 34-59.

Kuptsch, Christiane; Pang, Eng Fong 2006 (ed.): Competing for Global Talent. Geneva: ILO/IILS. [http://www.ilo.org/public/english/bureau/inst/download/competing.pdf, 23 July 2012].

Martin, Philip; Abella, Manolo; Kuptsch, Christiane 2006: Managing Labor Migration in the Twenty-first Century. Yale University Press: New Haven and London.

Minet, George 2001: Presentation at Conference 'Social Dialogue, Economic and Social Policy', Turin: International Training Centre ILO. [http://training.itcilo.it/decentwork/ staffconf2001/presentations/KUS4-report.doc, 23 July 2012].

MPI (Migration Policy Institute) 2009: Migration and the Global Recession. A Report Commissioned by the BBC World Service. URL: http://news.bbc.co.uk/2/shared/bsp/ hi/pdfs/08_09_09_migration.pdf, 23 July 2012.

OECD 2009: International migration and the economic crisis: Understanding the links and shaping policy responses. Working paper DELSA/ELSA/WP2(2009)3. URL: http:// www.oecd.org/officialdocuments/publicdisplaydocumentpdf/?cote=DELSA/ELSA/ WP2(2009)3\&docLanguage=En, 23 July 2012.

Passel, Jeffrey S.; Cohn, D’Vera 2009: Mexican Immigrants: How Many Come? How Many Leave? Washington: Pew Hispanic Center. [http://www.pewhispanic.org/2009/07/22/ mexican-immigrants-how-many-come-how-many-leave/, 23 July 2012].

Plewa, Piotr 2009: The 2008/2009 financial crisis: A false start for Czech foreign worker admissions? URL: http://www.age-of-migration.com/uk/financialcrisis/updates/1g. pdf, 23 July 2012.

Ripsman, Norrin 2004: False Dichotomy: When Low Politics is High Politics. Paper presented at the annual meeting of the International Studies Association, Montreal, Quebec, Canada, 17 March 2004; URL: http://www.allacademic.com/meta/p73388_index. html, 23 July 2012.

Sullivan, Tom 2008: Sweden's new immigration rules please employers. In: The Irish Times, 12 December 2008. [http://www.irishtimes.com/newspaper/ world/2008/1222/1229728441692.html / http://www.sullivantom.com/index.htm]

Sumption, Madeleine; Somerville, Will 2009: The UK's new Europeans. Progress and challenges five years after accession. Equality and Human Rights Commission, Migration Policy Institute. URL: http://www.equalityhumanrights.com/uploaded_files/ new_europeans.pdf, 23 July 2012.

Sward, Jon 2009: Assisted Voluntary Return (AVR): an Opportunity for Development? Development Research Centre on Migration, Globalisation \& Poverty, Briefing No. 20. September 2009. URL: http://www.migrationdrc.org/publications/briefing_papers/ BP20.pdf, 23 July 2012.

Sweetman, Arthur 2010: Spotlight on the economic effects of immigration - A North American perspective. In: Kuptsch, Christiane (ed.): The Internationalization of Labour Markets. Geneva: ILO/IILS. [http://www.ilo.org/public/english/bureau/inst/download/ interlabour.pdf, 23 July 2012]. 
ZAV (Zentralstelle für Arbeitsvermittlung - Central Placement Office, Germany) 2004: Merkblatt zur Vermittlung von Krankenpflegepersonal aus Kroatien und Slowenien nach Deutschland - Hinweise für Bewerber und Arbeitgeber. URL: http://www.hzz.hr/ docslike/D-novosti.pdf, 23 July 2012.

A German translation of this reviewed and author's authorised original article by the Federal Institute for Population Research is available under the title "Die Wirtschaftskrise und Arbeitsmigrationspolitik in Europa", DOI 10.4232/10.CPoS-2011-17de or URN urn:nbn:de:bib-cpos-2011-17de5, at http://WwW.comparativepopulationstudies.de.

Christiane Kuptsch* $(\bowtie)$. International Migration Branch, International Labour Office, Geneva, Switzerland. E-Mail: kuptsch@ilo.org. URL: http://www.ilo.org

\footnotetext{
Senior Specialist in Migration Policy, International Labour Office (ILO), Geneva. The views expressed are those of the author and do not necessarily reflect ILO positions.
} 


\section{Comparative Population Studies - Zeitschrift für Bevölkerungswissenschaft}

wWw.comparativepopulationstudies.de

ISSN: 1869-8980 (Print) - 1869-8999 (Internet)

Published by / Herausgegeben von

Prof. Dr. Norbert F. Schneider

Federal Institute for Population Research

D-65180 Wiesbaden / Germany

Managing Editor /

Verantwortlicher Redakteur

Frank Swiaczny

Editorial Assistant /

Redaktionsassistenz

Katrin Schiefer

Language \& Copy Editor (English) /

Lektorat \& Übersetzungen (englisch)

Amelie Franke

Copy Editor (German) /

Lektorat (deutsch)

Dr. Evelyn Grünheid

\section{Layout / Satz}

Beatriz Feiler-Fuchs

E-mail: cpos@destatis.de

\author{
Scientific Advisory Board / \\ Wissenschaftlicher Beirat \\ Jürgen Dorbritz (Wiesbaden) \\ Paul Gans (Mannheim) \\ Johannes Huinink (Bremen) \\ Marc Luy (Wien) \\ Clara H. Mulder (Groningen) \\ Notburga Ott (Bochum) \\ Peter Preisendörfer (Mainz)
}

\section{Board of Reviewers / Gutachterbeirat} Martin Abraham (Erlangen) Laura Bernardi (Lausanne) Hansjörg Bucher (Bonn) Claudia Diehl (Göttingen) Andreas Diekmann (Zürich) Gabriele Doblhammer-Reiter (Rostock) Henriette Engelhardt-Wölfler (Bamberg) E.-Jürgen Flöthmann (Bielefeld) Alexia Fürnkranz-Prskawetz (Wien) Beat Fux (Zürich) Joshua Goldstein (Rostock) Karsten Hank (Köln) Sonja Haug (Regensburg) Franz-Josef Kemper (Berlin) Michaela Kreyenfeld (Rostock) Aart C. Liefbroer (Den Haag) Kurt Lüscher (Konstanz) Dimiter Philipov (Wien) Tomáš Sobotka (Wien) Heike Trappe (Rostock) 